\title{
Perceived Causes and Intervention Options for Sustainable Resolution of Conflicts Among Cattle Herdsmen and Arable Crop Farmers in Ebonyi North Zone, Ebonyi State, Nigeria
}

\author{
Umeh, G.N ${ }^{1}$, Chukwu, V.A ${ }^{2}$ \\ ${ }^{1}$ Department of Agricultural Economics, Management and Extension, Ebonyi State University, P.M.B 053, Abakaliki, Ebonyi State, \\ Nigeria.
}

${ }^{2}$ Ebonyi State Agricultural Development Programme (EBADEP) P.M.B 040, Abakaliki, Ebonyi State, Nigeria.

\begin{abstract}
This study was on perceived causes and intervention options for sustainable resolution of conflicts among cattle herdsmen and arable crop farmers in Ebonyi North Zone, Ebonyi State, Nigeria. A combination of purposive and simple random sampling techniques was employed in the selection of 172 respondents (160 farmers and 12 herdsmen). Primary data were sourced through field survey with the aid of a well-structured questionnaire and interview schedule. Descriptive statistics were employed in data analysis. The result of data analysis showed that destruction of the farmers' crops by cattle was the greatest source of conflict (89.4\%) followed by contamination of sources of potable water (66.3\%). Other activities of herdsmen that caused conflict as perceived by the crop farmers were destruction of fences, destruction of smaller livestock such as incubating fowls, waste dropping on playgrounds and compaction of the farmers' farmland. Based on the herdsmen perception, beating of cattle by farmers (100\%) was the greatest source of conflict, followed by killing and injuring of cattle (87.5\%). However, raping of Fulani girls or women was not experienced by the Fulani community in the area. Other sources were abusing and cursing of Fulani herdsmen and blocking of roads by crop farmers. Identified consensus intervention options for sustainable peaceful coexistence among the farmers and Fulani herdsmen include encouraging Fulani herdsmen to learn the custom of their host community, compensation of aggrieved farmers and herders, punishment of the offenders, educating farmers and herdsmen on their inter-dependence and institution of as well as regular meeting of herdsmencommunity leaders' committee/forum. The study concluded that institution of stakeholders' forum among the two conflicting groups, compensation of the aggrieved herders or farmers and punishment of the offenders could be intervention options in conflict resolution. Recommendations such as restricting herdsmen to their own communities, provision of grazing reserves, as well as restricting herdsmen to particular locations were made, among others.
\end{abstract}

Keywords: Conflicts, Fulani Herdsmen, Arable Crops Farmers, Causes, Intervention Options, Ebonyi State, Nigeria.

\section{Introduction}

Economic livelihood activities in West Africa has experienced serious tension due to the conflict between crop farmers and nomadic cattle herders. The problem was mainly noticed in the savannah belt of West Africa in the period before the beginning of the $20^{\text {th }}$ Century. Cattle rearing were mainly prevalent in the Guinea, Sudan and Sahel savannah belts where crop production was carried out during the short rainy season on a small scale. This gave the cattle herders access to a vast area of grassland. However, with the introduction of irrigated farming in the savannah belt of Nigeria, and the less pasture availability to cattle herders to increased weathering of pasture in dry season, the herdsmen had to move alternative route i.e. southward to the coastal zone due to longer rainy season and the soil capacity retain moisture for long.

The large number of dangerous animals and the fear of losing their livestock to diseases, such as trypanosomiasis, made herders not to settle permanently in the humid zone (Blench, 1994). The consensus among observers revealed that crop farmers - herdsmen conflicts became widespread in the coastal countries of West Africa since the $20^{\text {th }}$ century (Tonah 2006). He further opined that the reasons that accounted for the widespread of crop farmers - herdsmen conflicts include the southward movement of nomadic herders into the forest and semi forest zones, which was due to the successful control of the menace posed by disease, the increased availability of veterinary medicine and the increased expansion of farming operations into areas that served as pasture land. Tonah (2006) also pointed out that since the 1950s, there has been a large increase in human and equally in livestock population in the coastal countries of West Africa. This gave rise to an increased demand on natural resources and a stiff competition for available resources between crop farmers and herdsmen (Adebayo, 1997, Breuser et al., 1998; Bernadet, 1999).

Tonah (2006) was of the view that since the 1970s and 1980s Sahelian drought which was accompanied by migration of a large number of pastoralists into the fringes of the forest zone of West Africa, there has been a massive increase of the incidence of crop farmers - herdsmen conflict. Ebii (2004) observed that Ivo Local Government of Ebonyi State, Nigeria is one of the areas the Fulani migrants settle with their cattle during dry season of every year (months of November - April the next year). Many farmers in the Local Government area may not quantify the damages caused by the activities of Fulani herdsmen and their animals on farms in the course of their yearly migration. There are number of difficulties and problems associated with the arrival of Fulani's and their cattle in an area, such 
Index Copernicus Value (2013): 6.14 | Impact Factor (2015): 6.391

as desertification, soil degradation, erosion and loss of farm crops. Bush burning is a valuable tool in the hands of the Fulani as this allows for easy movement of their cattle and growth of new pasture in the burnt area. The damages caused are enormous as agricultural activities in the area are hampered; unharvested crops in the farm are burnt and there is general loss of biodiversity in the area.

Much loss of lives, properties and environmental degradation in Nigeria has been attributed to the incessant resource conflict noticed in the tropics. Many cases of the conflicts between cattle rearers and crop farmers have been recorded (Okoroafor, 2009). In Ebonyi State for instance, notable cases were the conflict between Amasiri rice farmers and cattle rearers in 2008 in which many cattle and crops were damaged and some people were injured in Afikpo North Local Government Area. At Onuenyim village in Okpitumo community Abakiliki Government Area of the state, the crisis between farmers and cattle rearers resulted to the slaughtering of ten cattle by the farmers for destruction of their rice farms in the year 2005. In the same vein, at Ephugho village in the same Okpitumo community in the year 2006, the misunderstanding between the two parties crop farmers and Fulani herdsmen claimed two lives. Also at Oguzoronwiya Igbeagu, Izzi Local Government Area, six cattle were poisoned by a cassava farmer in 2009. Justifying further, Fosona and Omojola (2005) pointed out that land related cases accounted for about $51 \%$ of the major conflicts that occur between nomadic herders and crop farmers, and herdsmen accounted for $35 \%$ of all the reported crises while politics, religious and also ethnic clashes recorded lower frequencies of the conflicts.

The study carried out by Nyong and Fiki (2005) of 27 communities in North central Nigeria revealed that over $40 \%$ of the households examined had experienced agricultural land related conflicts, some respondents also recalled conflicts that were as far back as 1965 and also as recent as 2005. Although, numerous researches have been conducted on arable farmers and nomadic herders conflicts in Nigeria, there seem to exist no documented data on the causes of and intervention options for Fulani herdsmen and arable crop farmers conflicts in Ebonyi North Agricultural zone of Ebonyi State, Nigeria.

Herdsmen - crop farmers' conflicts are threats to peace and national stability since it may jeopardize tribal co-existence, as Nigeria is a multi-ethnic and multi-tribal nation. It is therefore, imperative to critically analyze this phenomenon with a view to resolve all contentious issues for peaceful coexistence between the groups on sustainable basis.

\section{Objectives of the Study}

The broad objective of the study was to analyze Fulani herdsmen - crop farmers' conflicts in Ebonyi North Agricultural zone of Ebonyi State, Nigeria. The Specific objectives were to:

1) identify sources of farmers - herdsmen conflicts in the area in the past five years; and

2) analyze intervention options for sustainable resolution of the conflicts.

\section{Methodology}

The study was conducted in Ebonyi North Zone of Ebonyi State, Nigeria, which lies appropriately on latitude 70.30 'N and longitude $50.40^{\prime} \mathrm{E}$ and $50.45^{\prime} \mathrm{E}$ in the South East geopolitical zone of Nigeria. Purposive sampling technique was adopted in the selection of two (2) autonomous communities that are endemic to herdsmen/crop farmers' conflict from each of the four (4) local government areas in the zone. Then, simple random sampling techniques were used to select five (5) villages from each of the selected communities to give a total of (40) villages. From each village, four (4) arable crop farmers were systematically selected to give a total of one hundred and sixty (160) farmers. However, two Fulani cattle rearers were randomly selected from each of the selected eight (8) autonomous communities to give a total of sixteen (16) Fulani herdsmen. Thus, a total of one hundred and seventy two (172) respondents were used for the study. Primary data were sourced by the use of structured questionnaire and interview schedule. Descriptive statistics such as frequency counts, percentages and means scores derived from 4-point Likert type scale with decision point of 2.5 were employed in data analysis. Focus group discussion (FGD) was also conducted to support the findings from data analysis with qualitative information.

\section{Results and Discussion}

Data analysis and results discussion of the study were presented according to specific objectives of the study.

\section{Sources of Farmers - Herdsmen Conflicts in the Area in the Past Five Years}

The sources of farmers -herdsmen conflict were sought and analyzed. The result obtained is shown in Table 1. 


\section{International Journal of Science and Research (IJSR) \\ ISSN (Online): 2319-7064}

Index Copernicus Value (2013): 6.14 | Impact Factor (2015): 6.391

Table 1: Percentage distribution of Arable Crop farmers according to Perceived sources of conflicts

\begin{tabular}{lcc}
\hline \multicolumn{1}{c}{ Sources of Conflict } & Frequency & Percentage \\
\hline Crop(s) destroyed by herdsmen/cattle & 143 & 89.4 \\
Your sources of potable water contaminated & 106 & 66.3 \\
by herdsmen/cattle & & \\
Herdsmen violated local customs & 71 & 44.4 \\
Herdsmen involved in raping young girls/women & 27 & 16.9 \\
Herdsmen did set fire on farm plots & 101 & 63.1 \\
Herdsmen fought children/relations & 64 & 40.0 \\
Herdsmen stole crops/properties & 48 & 30.0 \\
\hline
\end{tabular}

Source: Field Survey, 2015.

The result of data analysis in Table 1 actually presented the percentage distribution of crop farmers' responses on the causes of crop farmers-herdsmen conflicts. The study revealed that the major causes of the conflicts were destruction of crops by herdsmen and their cattle $(89.4 \%)$, contamination of sources of potable water $(66.3 \%)$ by herdsmen/cattle and setting of fire on farm plots $(63.1 \%)$. This is in line with Blench (1994) report, that the major cause of herdsmen-farmers' conflicts in Nigeria is the destruction of farmers' crop by herdsmen cattle. Other activities of herdsmen/cattle that caused conflicts as revealed in focus group discussion with the crop farmers were; destruction of fences, stepping on incubating fowls by cattle, dropping of wastes on their playground and compacting of farmland thereby making farmland harder during cultivation.

\section{Sources of farmers-Herdsmen Conflicts as indicated by the Herdsmen}

Most of the herdsmen respondents indicated that they have been involved on conflicts many times within the period. The result obtained is shown in Table 2.

Table 2: Distribution of Herdsmen according to Perceived Sources of the Conflicts

\begin{tabular}{lcc}
\hline \multicolumn{1}{c}{ Sources of Conflict } & Frequency & Percentage \\
\hline Cattle killed by crop farmers & 14 & 87.5 \\
Cattle injured by crop farmers & 14 & 87.5 \\
Properties stolen by crop farmers/relations & 6 & 37.5 \\
Cattle were beaten & 16 & 100.0 \\
The boys raped your girls/women & - & - \\
Children were harassed and beaten by crop & 3 & 18.8 \\
$\quad$ farmers/relations & 16 & 100.0 \\
Cattle trespassed their farmland & 14 & 87.5 \\
Cattle drank from their sources of water & & \\
Did not pay or complete the payment after & 9 & 56.3 \\
$\quad$ buying your cattle & & \\
\hline
\end{tabular}

\section{Source: Field Survey, 2015.}

The result of data analysis in Table 2 indicated that, among the sources of conflict perceived by the herdsmen, beating of the cattle by farmers and Fulani cattle trespass over farm land recorded $100 \%$ each. The herdsmen equally indicated that killing and injuring of their cattle, as well as potable water contamination by their herd were among the major causes of farmers-herdsmen conflicts $(87.5 \%)$. The study also revealed that raping of Fulani girls or women was not experienced by the Fulani community in the area. This is in conformity with Nweze (2005) findings that killing and injuring of herdsmen cattle are among the causes of herdsmen-farmers conflicts. Other activities by crop farmers as revealed by focus group discussion with herdsmen that contributed to conflicts include abusing and cursing of Fulanis by crop farmers and blocking of roads by crop farmers, thereby preventing them and their cattle from passing.

Intervention options for sustainable Resolution of Crop Farmers - Herdsmen Conflicts

Intervention option for sustainable resolution of crop farmers-herdsmen conflicts was determined by mean score obtained from 4-point likert scale. The result of data analysis is shown in Tables 3 and 4. 


\section{International Journal of Science and Research (IJSR) \\ ISSN (Online): 2319-7064 \\ Index Copernicus Value (2013): 6.14 | Impact Factor (2015): 6.391}

Table 3: Arable Crop Farmers' Perceived Intervention Options for Sustainable Resolution of Crop Farmers-Herdsmen Conflicts in the Study Area

\begin{tabular}{|c|c|c|c|c|c|c|}
\hline Intervention Options & SA & $\mathbf{A}$ & D & SD & $\mathbf{X}$ & Decision \\
\hline Each community to provide adequate grazing & & & & & & \\
\hline Reserves for Herdsmen. & 36 & 27 & 47 & 50 & 2.3 & Rejected \\
\hline $\begin{array}{l}\text { Herdsmen to rear their cattle along federal } \\
\text { Roads only. }\end{array}$ & 46 & 22 & 34 & 58 & 25 & A crented \\
\hline Restricting the number of cattle to the carrying & 40 & 22 & 34 & Jo & 2.5 & Acoepred \\
\hline $\begin{array}{l}\text { Capacity of host community grassland. } \\
\text { Curriculum of nomadic education to include the }\end{array}$ & 36 & 63 & 42 & 19 & 3.4 & Accepted \\
\hline $\begin{array}{l}\text { Sustainability of ecosystem/farmland. } \\
\text { Encourage Fulani to leam the custom of the host }\end{array}$ & 72 & 55 & 25 & 8 & 3.2 & Accepted \\
\hline $\begin{array}{l}\text { Community. } \\
\text { Legislation to confine cattle to particular }\end{array}$ & 79 & 48 & 18 & 15 & 3.1 & Accepted \\
\hline locations. & 56 & 72 & 20 & 12 & 3.2 & Accepted \\
\hline $\begin{array}{l}\text { Compensation of aggrieved farmers and } \\
\text { herders. }\end{array}$ & 86 & 50 & 16 & 8 & 3.4 & Accepted \\
\hline $\begin{array}{l}\text { Punishment of the offender(s). } \\
\text { Educating farmers and herdsmen on their }\end{array}$ & 89 & 57 & 4 & 10 & 3.5 & Accepted \\
\hline $\begin{array}{l}\text { Inter-independence. } \\
\text { Institution of, and regular meeting of herdsmen }\end{array}$ & 88 & 62 & 8 & 2 & 3.5 & Accepted \\
\hline $\begin{array}{l}\text {-Community leaders }{ }^{2} \text { committee forum. } \\
\text { Leasing out grazing land by the community to }\end{array}$ & 77 & 59 & 12 & 12 & 3.3 & Accepted \\
\hline herdsmen. & 36 & 30 & 33 & 61 & 2.3 & Rejected \\
\hline
\end{tabular}

Source: Field Survey, 2015.

Note: SA - Strongly Agreed, A - Agreed, D - Disagreed, SD - Strongly Disagreed

Result presented in Table 3 showed that almost all the intervention options for sustainable resolution of crop farmers -herdsmen conflicts were accepted by the respondents. This is confirmed by the fact that the mean score obtained from the respondents (crop farmers) were higher than or equal to 2.5 in accordance with the decision rule. The result indicated that punishment of the offender(s) had the highest mean score of $(X=3.5)$ and closely followed by restricting the number of cattle to the carrying capacity of host community grassland $(\mathrm{X}=3.4)$ and compensation of aggrieved farmers and herders $(\mathrm{X}=3.4)$. The respondents (farmers) rejected two options as means of resolving crop farmers - herdsmen conflicts. The options were each community to provide adequate grazing reserves for herdsmen $(X=2.3)$ and leasing out grazing land by the community to herdsmen $(\mathrm{X}=2.3)$.

Table 4: Herdsmen Perceived Intervention options for Sustainable Resolution of Crop farmers - Herdsmen Conflicts in the Study Area

\begin{tabular}{|c|c|c|c|c|c|c|}
\hline $\begin{array}{l}\text { Intervention Options } \\
\text { Each community to provide adequate grazing }\end{array}$ & $\mathrm{SA}$ & $\bar{A}$ & $\bar{D}$ & SD & $\bar{X}$ & Decision \\
\hline $\begin{array}{l}\text { Reserves for Herdsmen. } \\
\text { Herdsmen to rear their cattle along federal }\end{array}$ & 4 & 4 & 6 & 2 & 2.7 & Accepted \\
\hline $\begin{array}{l}\text { Roads only. } \\
\text { Restricting the number of cattle to the carrying }\end{array}$ & 0 & 2 & 9 & 5 & 1.8 & Rejected \\
\hline $\begin{array}{l}\text { Capacity of host community grassland. } \\
\text { Curriculum of nomadic education to include the }\end{array}$ & 0 & Q & 4 & 12 & 1.3 & Rejected \\
\hline $\begin{array}{l}\text { Sustainability of ecosystem/farmland. } \\
\text { Encourage Fulani to leam the custom of the host }\end{array}$ & 0 & 4 & 7 & 5 & 2.0 & Rejected \\
\hline $\begin{array}{l}\text { Community. } \\
\text { Legislation to confine cattle to particular }\end{array}$ & 2 & 8 & 3 & 3 & 3.0 & Accepted \\
\hline $\begin{array}{l}\text { Locations. } \\
\text { Compensation of aggrieved farmers and }\end{array}$ & 0 & 0 & 4 & 12 & 1.3 & Rejected \\
\hline $\begin{array}{l}\text { Herders. } \\
\text { Punishment of the offender(s). } \\
\text { Educating farmers and herdsmen on their }\end{array}$ & $\begin{array}{l}6 \\
5\end{array}$ & $\begin{array}{l}10 \\
5\end{array}$ & $2^{0}$ & $4^{9}$ & $\begin{array}{l}3.4 \\
2.8\end{array}$ & $\begin{array}{l}\text { Accepted } \\
\text { Accepted }\end{array}$ \\
\hline $\begin{array}{l}\text { Inter-independence. } \\
\text { Institution of and regular meeting of herdsmen }\end{array}$ & 4 & 8 & 2 & 2 & 2.9 & Accepted \\
\hline $\begin{array}{l}\text { Community leaders" committee forum. } \\
\text { Leasing out grazing land by the community to }\end{array}$ & 2 & 9 & 2 & 3 & 2.7 & Accepted \\
\hline & 10 & 2 & 2 & 2 & 3.5 & Accepted \\
\hline
\end{tabular}

Source: Field Survey, 2013

Note: SA - Strongly Agreed, A-Agreed D-Disagreed and SD -Strongly Disagreed

Analysis presented in Table 4 shows that respondents (herdsmen) accepted some of the intervention options and rejected others. The result indicated that leasing out grazing land by the community to herdsmen recorded the highest mean score of 3.5 and closely followed by compensation of aggrieved farmers and herders $(X=3.4)$. Other acceptable options include encouraging Fulani herdsmen to learn the customs of the host community $(X=3.0)$, educating farmers 


\section{International Journal of Science and Research (IJSR) \\ ISSN (Online): 2319-7064}

Index Copernicus Value (2013): 6.14 | Impact Factor (2015): 6.391

and herdsmen on their interdependence $(X=2.8)$ and institution of and regular meeting of herdsmen community leaders committee/forum $(X=2.7)$. However, the rejected intervention options were; restricting the number of cattle to the carrying capacity of host community grassland $(X=1.3)$, legislation to confine cattle to particular locations $(X=1.3)$, herdsmen to rear cattle along federal roads only $(X=1.8)$ and curriculum of nomadic education to include the sustainability of ecosystem/farmland $(X=2.0)$.

\section{Conclusion}

The study identified the major causes of conflicts between the herdsmen and arable crop farmers as both social and economic in nature. The economic perspective to the conflict include destruction of farmers' crops by the Fulani cattle and non-payment or incomplete payment for purchasing cattle by the farm community members. Violation of women and the customs of the farm community by the herdsmen and blocking of roads, thereby denying herders and their cattle access through the community by the farmers, constituted the major social challenge to peaceful co-existence of the Fulani herders and the farmers. Consensus measures for sustainable resolution of herdersfarmers conflict in the area include the institution of stakeholders' forum made up of both groups to supervise, oversee and resolve issues affecting the farmers and herders, compensation of aggrieved herders or farmers and punishment of the offenders as well as educating farmers and herdsmen on their inter-dependence.

\section{Recommendations}

Based on the findings of the study, the following recommendations were added to the consensus measures for sustainable peaceful coexistence among the two parties;

1) Access to land resources is a major cause of herderfarmers conflicts in Ebonyi North Agricultural zone that leads to crop destruction, local authorities should ensure that there is equitable and regulated access to arable and grazing land to both parties to avert constant conflicts,

2) Laws restricting the number of animals (cattle) to the carrying capacity of the grassland in all communities should be enacted in order to avoid over-grazing and destruction of ecosystem in Ebonyi State,

3) government at all levels should provide grazing reserves to accommodate the interest of herdsmen since cattle is the major source of protein (meat) in Nigerian markets,

4) the leaders of nomadic Fulani should encourage their community to learn the customs guiding their host community to avoid violation which often leads to conflict,

5) the Federal Governments of Nigeria should enact a law that will confine herdsmen and their animals to particular locations. This will reduce the frequent clashes between the rival groups.

\section{References}

[1] Adebayo A. (1997). Contemporary dimensions of migration among historically migrant Nigerians. Journal of Asian African Studies 32. Pp 93 - 109.
[2] Bermadet P. (1999). Peuls en Conflicts en moyenne et heute cote d'Ivoire de 1950 a 1990 . Pp: 407- 444.

[3] Blench R. (1994). The expansion and adaptation of Fulani pastoralism to sub humid and humid condition in Nigeria $P p: 197-213$.

[4] Blench R. M. (2003). Report on Fadama user conflicts in Kebbi and Imo States. Unpublished report to the World Bank.

[5] Breusers M. (1998). Conflict or Symbiosis? Disentangling farmer-herdsmen relationship: the mossi and Fulani of the Central Plateau pp 357 - 380.

[6] Ebii C. O. (2004). Farming System and Bushfire Culture. An Environmental Issue in Ishiagu, Ebonyi State, Nigeria. Proceedings of the Academic Seminar series of Federal College of Agriculture vol 1, $12-15$.

[7] Fasona M. J. Omojola (2005). Climate Change, Human Security and Communal Clashes in Nigeria. Paper at International Workshop in Human Society and Climate change, Holmen Fjord Hotel, Oslo Oct. 21 - 23, 2005, pp $3-13$.

[8] Fiki C. Lee B. (2004). Conflict Generation, Conflict Management and Self-Organizing capabilities in Drought-prone rural communities in North-Eastern Nigeria: A case study. Journal of Social Development in Africa, Pp: 25-48.

[9] Nweze N. J. (2005). Minimizing Farmer-herder conflict in Fadama areas through Local Development plans: Implication for Increased crop-livestock productivity in Nigeria. Paper presented at the $30^{\text {th }}$ Annual Conference of the Nigeria Society for Animal Production, held $20^{\text {th }}$ $-24^{\text {th }}$ March.

[10] Okoroafor O. (2009). Annual Report in the office of the Director, Livestock and Fisheries; Ministry of Agriculture and Natural Resources Ebonyi State. Pp 120 $-231$.

[11]Tonah S. (2006). Managing Farmer-Herder Conflict in Ghana's volta Basin, Ibadan Journal of Social Sciences 4(1): $33-165$. 